ISSN 1678-3921

Journal homepage: www.embrapa.br/pab

For manuscript submission and journal contents, access: www.scielo.br/pab

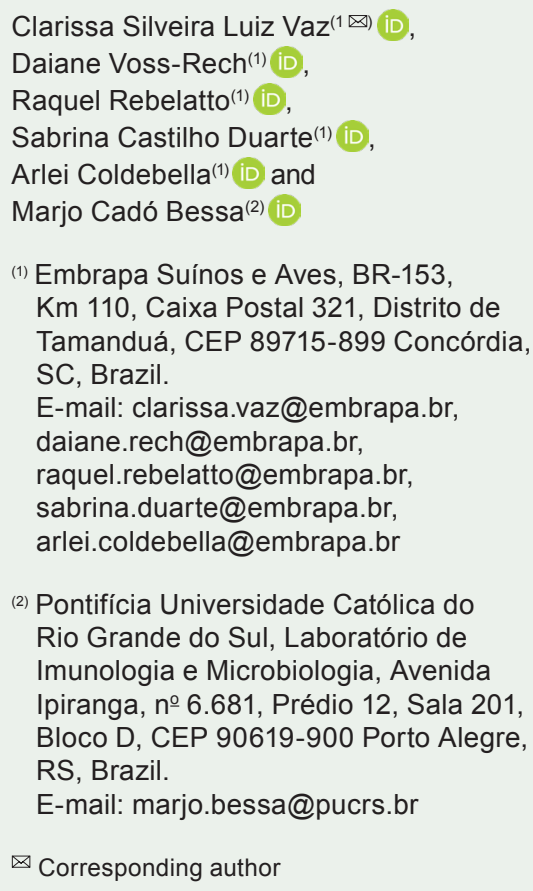

\section{Survival of Campylobacter jejuni in chicken at refrigeration and cooking temperatures}

\begin{abstract}
The objective of this work was to evaluate the reduction of Campylobacter jejuni in chicken meat at 6 and $70^{\circ} \mathrm{C}$, after the inoculation of a Brazilian strain. The kinetics of $C$. jejuni survival showed a 0.26 $\log \left(\mathrm{CFU} \mathrm{g} \mathrm{g}^{-1}\right)$ decrease for each day of exposure at $6^{\circ} \mathrm{C}$, and a $1.35 \log$ $\left.(\mathrm{CFU} \mathrm{g})^{-1}\right)$ decrease for each $1 \log$ increase at $70^{\circ} \mathrm{C}$. Although reduced levels of C. jejuni were found after regular intervals at both temperatures, its incomplete inactivation underlines the need of good hygiene practices for consumers to avoid campylobacteriosis.
\end{abstract}

Index terms: broiler meat, foodborne pathogen, food safety, reduction kinetics.

\section{Sobrevivência de Campylobacter jejuni em carne de frango a temperaturas de refrigeração e cozimento}

Resumo - O objetivo deste trabalho foi determinar a redução de Campylobacter jejuni em carne de frango a 6 e $70^{\circ} \mathrm{C}$, após inoculação de uma cepa brasileira. A cinética de sobrevivência de C. jejuni mostrou redução de $0,26 \log \left(\mathrm{UFC} \mathrm{g}^{-1}\right)$ a cada dia de exposição a $6^{\circ} \mathrm{C}$ e redução de $1,35 \log$ $\left(\mathrm{UFC} \mathrm{g}{ }^{-1}\right.$ ) para cada aumento de $1 \log$ a $70^{\circ} \mathrm{C}$. Embora níveis reduzidos de C. jejuni sejam encontrados após intervalos regulares de exposição a ambas as temperaturas, a inativação incompleta ressalta a necessidade de boas práticas de higiene para os consumidores evitarem a campilobacteriose.

Termos para indexação: patógeno alimentar, segurança dos alimentos, carne de ave, cinética de redução.

Campylobacter is a main cause of bacterial foodborne enteritis (Hansson et al., 2018; The European..., 2019). All thermotolerant Campylobacter are known to cause infection; however, C. jejuni accounts for most laboratory-confirmed human cases (The European..., 2019), and it is the most common species detected in chicken samples in Brazil (Melo et al., 2019; Ramires et al., 2020; Pozza et al., 2020). Human campylobacteriosis has been primarily related to contaminated drinking water and food of animal origin. Although it is ubiquitous in the environment, high loads of $C$. jejuni often colonize the gastrointestinal tract of broilers, and carcasses can become contaminated in slaughterhouses (Hansson et al., 2018). As a result, the mishandling or consumption of undercooked chicken is a leading risk factor for human infection (The European..., 2019). 
Because highly contaminated chicken has been associated with a higher probability of causing foodborne campylobacteriosis, it is accepted that the most effective intervention measures in food chain rely on reducing Campylobacter numbers in chicken products (Hansson et al., 2018). Campylobacter spp. are fastidious bacteria, sensitive to high and low temperatures (Al-Sakkaf, 2015; Hansson et al., 2018). Therefore, physical interventions, such as chilling or freezing, reduce the contamination of chicken (Sampers et al., 2010; Boysen et al., 2013; Casagrande Proietti et al., 2018) and may result in a lower risk of consumer infection. Nevertheless, retail storage conditions for poultry meat often facilitate the Campylobacter survival at lower temperatures (Ritz et al., 2007; Hansson et al., 2018), while safety at the consumer stage relies on domestic kitchen practices, including food hygiene and appropriate cooking (Membré et al., 2013; Al-Sakkaf, 2015; Langsrud et al., 2020).

Laboratory studies allow to estimate the effect of domestic decontamination procedures for the Campylobacter number on artificially contaminated chicken. However, the mean log reduction of Campylobacter by physical decontamination of chicken is strongly dependent on the tested strains (Boysen et al., 2013; Al-Sakkaf, 2015; Gomes et al., 2018). Studies on $C$. jejuni survival in laboratory to date have only focused on strains isolated in other countries (Boysen et al., 2013; Al-Sakkaf, 2015), which make it difficult to compare the effect of such strategies on pathogen reduction.

The objective of this work was to evaluate the reduction of $C$. jejuni in chicken meat at 6 and $70^{\circ} \mathrm{C}$, after the inoculation of a Brazilian strain.

The C. jejuni strain BRM 48963 isolated from chicken in southern Brazil in 2014 was provided by the microbial culture collection of Embrapa Suínos e Aves, in the municipality of Concórdia, state of Santa Catarina. Such a strain was chosen based on a distinct SmaI-pulsed-field gel electrophoresis pattern compared with other available isolates from chicken samples. Stock culture was kept in the laboratory at $-70^{\circ} \mathrm{C}$ in Nutrient Broth n. 2 (Oxoid, Basingstoke, Hampshire, UK) supplemented with $0.6 \%$ yest extract (Merck, Darmstadt, Hesse, Germany), 0.025\% ferrous sulfate (Vetec, Duque de Caxias, RJ, Brazil), 0.025\% sodium metabisulfite (Vetec), $0.025 \%$ sodium pyruvate (Sigma-Aldrich, St. Louis, MO, USA), 10\% fetal bovine serum (Thermo Fischer Scientific, Waltham, MA, USA), and 10\% glycerol (Thermo Fischer Scientific). Working stocks were stored on Brucella broth (BD Difco, Detroit, MI, USA) with $1.8 \mathrm{~g} \mathrm{~L}^{-1}$ agar and $0.02 \mathrm{~g}$ $\mathrm{L}^{-1}$ neutral red, in untightened screw cap tubes at $37^{\circ} \mathrm{C}$ in aerobic conditions, and were subcultured weekly.

Chilled chicken drumsticks samples were obtained from local supermarkets and tested for microbiological detection of thermotolerant Campylobacter. The samples were rinsed with $150 \mathrm{~mL}$ of $0.1 \%$ buffered peptone water (BPW). Ten $\mathrm{mL}$ were inoculated in 90 $\mathrm{mL}$ of Bolton broth (Oxoid) supplemented with 5\% lysed horse blood, $0.02 \mathrm{~g} \mathrm{~L}^{-1}$ of cefoperazone, $0.02 \mathrm{~g} \mathrm{~L}^{-1}$ of vancomycin, $0.02 \mathrm{~g} \mathrm{~L}^{-1}$ trimethoprim and $0.01 \mathrm{~g} \mathrm{~L}^{-1}$ of amphotericin B (Sigma-Aldrich). After incubation in microaerobic atmosphere at $37^{\circ} \mathrm{C}$ for 4-6 hours and, then, at $41.5^{\circ} \mathrm{C}$ for $24 \mathrm{~h}$, the samples were concurrently streaked in modified charcoal cefoperazone deoxycholate agar (mCCD, HiMedia, Mumbai, Maharashtra, India) supplemented with $0.032 \mathrm{~g} \mathrm{~L}^{-1}$ cefoperazone and $0.01 \mathrm{~g} \mathrm{~L}^{-1}$ amphotericin B (SigmaAldrich), and Preston agar (Oxoid) supplemented with 5,000 IU L $\mathrm{I}^{-1}$ polymyxin $\mathrm{B}, 0.01 \mathrm{~g} \mathrm{~L}^{-1}$ rifampicin, 0.01 $\mathrm{g} \mathrm{L}^{-1}$ trimethoprim, and $0.01 \mathrm{~g} \mathrm{~L}^{-1}$ amphotericin $\mathrm{B}$ (Sigma-Aldrich). The plates were incubated at $41.5^{\circ} \mathrm{C}$ for 24-48 hours in microaerobic atmosphere $\left(5 \% \mathrm{O}_{2}\right.$, $10 \% \mathrm{CO}_{2}$, with balanced $\mathrm{N}_{2}$; White Martins, Rio de Janeiro, RJ, Brazil). After microscopy, presumptive Campylobacter colonies from each selective agar were subcultured in Blood agar no. 2 (Oxoid), for 24 hours at $41.5^{\circ} \mathrm{C}$ in microaerobic atmosphere, and confirmed by oxidase, sodium hippurate hydrolysis, and indoxyl acetate hydrolysis.

The C. jejuni BRM 48963 was grown at $41.5^{\circ} \mathrm{C}$ onto mCCD agar plates for 48 hours in microaerobic atmosphere. Colonies harvest from the agar surface were resuspended in $0.1 \% \mathrm{BPW}$ and adjusted to approximately $2.4 \times 10^{9} \mathrm{CFU}$ (colony-forming unit) $\mathrm{mL}^{-1}$, as suggested in a previous study on Campylobacter survival (de Jonge, 2019). The inoculum was measured by conventional plate counting in $\mathrm{mCCD}$ agar incubated at $41.5^{\circ} \mathrm{C}$ for 48 hours in microaerobic atmosphere. Skinless chickens were used in the present study, as proposed by Boysen et al. (2013). Fragments $\left(25 \mathrm{~cm}^{2}\right)$ were aseptically cut from chilled drumsticks that tested negative for thermotolerant Campylobacter. Cuts were individually placed onto Petri dishes and weighed. Next, a micropipette was used to spread the 
C. jejuni inoculum over the surface of each fragment to obtain the initial concentration of approximately $10^{6} \mathrm{CFU} \mathrm{\textrm {g } ^ { - 1 }}$. After $30 \mathrm{~min}$ at room temperature, in a laminar flow cabinet, in order to allow Campylobacter cells attachment, samples were individually transferred to sterile homogenization bags and subjected to two independent trials to determine the kinetics of $C$. jejuni reduction at regular intervals.

In a first trial, bags with contaminated chicken fragments were placed in a refrigerator to determine the survival at $6^{\circ} \mathrm{C}$ after 0,24 , and 72 hours. In total, 16,15 , and 12 chicken fragments were analyzed in each time, respectively. The second trial evaluated the survival at cooking temperature. Contaminated chicken fragments in the homogenization bags were transferred to a water bath at $70^{\circ} \mathrm{C}$ for $0,2,4,8,16$, and $32 \mathrm{~min}$. Respectively, 12 chicken fragments were analyzed at each 0-, 2-, and 4-min interval; and 11 chicken fragments were analyzed at each 8-, 16- and 32-min interval. In both trials, the analyses were distributed in three experimental blocks comprised of each combination of the number of chicken fragments, temperature, and regular intervals.

The number of $C$. jejuni was immediately quantified after each regular time in each given trial. Ten $\mathrm{mL}$ of $0.1 \%$ BPW was added to the individual chicken fragments, which were then homogenized in a stomacher at $230 \mathrm{rpm}$ for $60 \mathrm{~s}$ and subjected to serial decimal dilution. From each dilution, $0.1 \mathrm{~mL}$ was spread onto $\mathrm{mCCD}$ agar plates and incubated at $41.5^{\circ} \mathrm{C}$ for 48 hours in microaerobic atmosphere. The detection limit was $100 \mathrm{CFU}$ per sample. At least one typical colony counted as Campylobacter from each mCCD plate was confirmed from subculture in Columbia Blood agar (Oxoid), at $41.5^{\circ} \mathrm{C}$ for $24-48$ hours by microscopic analysis, sodium hippurate, and indoxyl acetate hydrolysis tests. The strain C. jejuni ATCC 33560 was used as positive control. Colony counts were converted into $\left.\log _{10}(\mathrm{CFU} \mathrm{g})^{-1}\right)$. The results were subjected to the variance analysis for the model containing the exposure time and experimental block effects, followed by regression analysis for the effect of exposure time on each trial. The analyses were carried out using SAS (version 9.4, SAS Institute, Cary, NC, USA). The minimum significance considered was $5 \%$ probability.

The results showed that $C$. jejuni counts reduced over time in chicken fragments at $6^{\circ} \mathrm{C}$ and $70^{\circ} \mathrm{C}$. The
F-test in the variance analysis detected significant effects for exposure time and experimental block, at $5 \%$ probability, on the survival of $C$. jejuni in chicken at both evaluated temperatures. Exposure to $6^{\circ} \mathrm{C}$ resulted in a $0.26 \log$ linear reduction of $C$. jejuni $\left(\mathrm{CFU} \mathrm{g}^{-1}\right)$ for each day of evaluation (Figure 1). Interestingly, a metaanalysis has found a log linear effect of temperature within a range of 0 to $42^{\circ} \mathrm{C}$ on Campylobacter survival, highlighting an ability to persist under $4^{\circ} \mathrm{C}$ for almost two weeks on a meat matrix (Membré et al., 2013). Although an in vitro analysis have shown the ability of Campylobacter coli Brazilian strains to grow at $4^{\circ} \mathrm{C}$ for 24 hours in microaerobic conditions, after inoculation in Brain Heart Infusion (BHI) broth (Gomes et al., 2018), it should be noted that thermotolerant Campylobacter are unable to multiply in foods under retail or household storage at low temperatures (Ritz et al., 2007; Membré et al., 2013; Al-Sakkaf, 2015). As found in the present study, the reduced level of $C$. jejuni during chilled storage of chicken has been reported in comparison with the initial contamination level (Sampers et al., 2010; Casagrande Proietti et al., 2018), but without achieving the pathogen inactivation. Therefore, storage at $4^{\circ} \mathrm{C}$ offers a risk of transfer of residual surviving Campylobacter from contaminated chicken.

In addition, the time of exposure to $70^{\circ} \mathrm{C}$ showed a nonlinear effect on the $C$. jejuni number on the surface of the chicken fragments (Figure 2). Based on the resulting equation, the estimated parameters

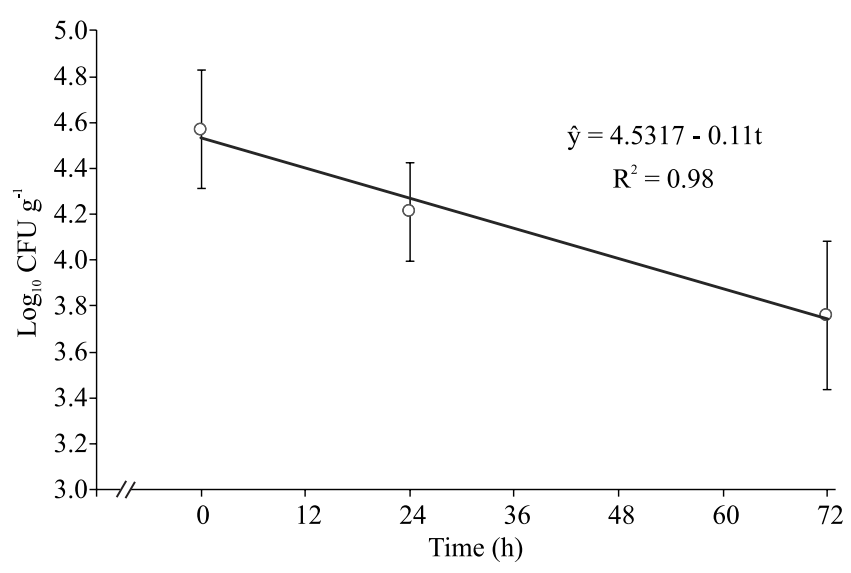

Figure 1. Effect of refrigeration at $6^{\circ} \mathrm{C}$ on the kinetics survival of a Campylobacter jejuni Brazilian strain (BRM 48963) in artificially contaminated skinless chicken fragments in function of time. 
showed $1.35 \log$ reduction of C. jejuni (CFU g-1) for each increase of $1 \mathrm{log}$ in the exposure period in minutes at $70^{\circ} \mathrm{C}$ (Figure 2). The thermal inactivation of Campylobacter depends on the adequate distribution of the temperature in the foodstuff (Al-Sakkaf, 2015; Lahou et al., 2015). Whereas Campylobacter numbers in artificially inoculated chicken burgers have dropped below detectable levels, after 4 min of frying, when core temperature has reached $57.5^{\circ} \mathrm{C}$ (Sampers et al., 2010), other authors showed that the core temperature of $70^{\circ} \mathrm{C}$ in hamburgers is not always reached during the regular cooking time, allowing Campylobacter to survive (Lahou et al., 2015). Moreover, Campylobacter survival was detected on chicken breast fillet surfaces that were not in contact with a frying plate, even when the core temperature reached $70^{\circ} \mathrm{C}$ (Langsrud et al., 2020). From these results, it can be assumed that heating of meat may vary among simulated cooking practices used in different laboratory studies. The temperature balance between the core and the surface of the artificially inoculated chicken fragments seems to be crucial to Campylobacter inactivation, which may have been delayed using the water bath in the present study.

It has been suggested that the attachment to meat contributes to an increased level of heat resistance of foodborne bacteria (de Jonge, 2019). In fact, Campylobacter survival times in laboratory trials are significantly shorter in liquid media than in meat

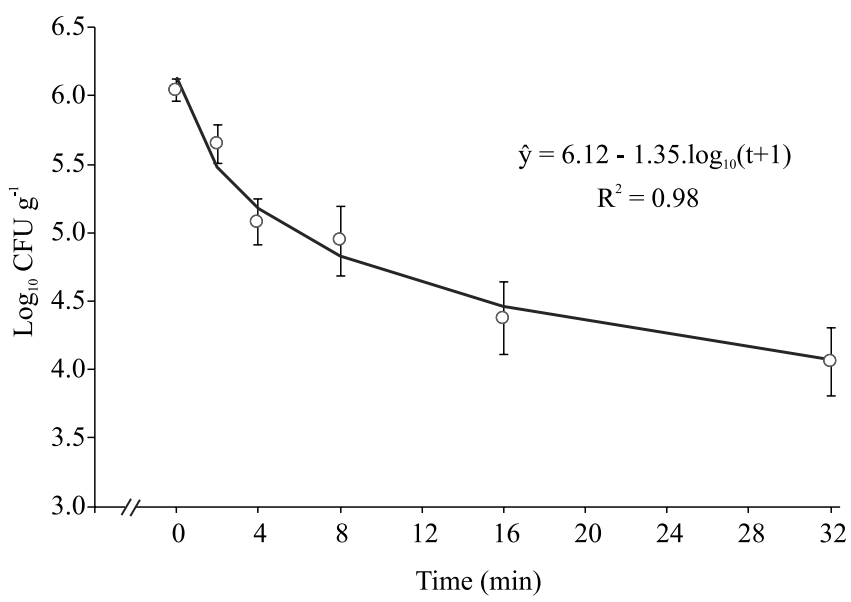

Figure 2. Effect of cooking at $70^{\circ} \mathrm{C}$ on the kinetics survival of a Campylobacter jejuni Brazilian strain (BRM 48963), in artificially contaminated skinless chicken fragments in function of time.
(Membré et al., 2013). Likewise, a previous study reported the thermal inactivation of Salmonella enterica ssp. enterica serotype Typhimurium at a faster rate when inoculated directly in phosphate-buffered saline, in comparison with the same strain attached to the chicken surface, which could be explained by the effect of the more homogeneous distribution of the temperature in buffer on the bacteria (de Jonge, 2019). Moreover, differences derived from the meat used as a model to study Campylobacter survival in foods have been drawn from other studies. For instance, C. jejuni inactivation due to freezing was less marked on the surface of chicken cut muscle than in skinned muscle, showing a variability according to the different meat surface types (Ritz et al., 2007). Therefore, the results from the present study on skinless chicken cannot be extrapolated to other chicken meat matrices.

The presence of residual survivors in meat after thermal processing also varies, depending on the initial number of microorganisms (Sampers et al., 2010). According to Boysen et al. (2013), Campylobacter reduction obtained with a high inoculation level in chicken might lead to a greater effect than that seen for lower contamination levels, which emphasizes the need for studies using naturally contaminated samples. However, it is noteworthy that levels of pathogens in chicken at the retail level are low (Langsrud et al., 2020), which was according to a previous study that showed average Campylobacter counts of $3.10 \pm 0.15$ $\log _{10}$ CFU per chicken sample (average weight of $753.24 \mathrm{~g}$ ) in southern Brazil (Pozza et al., 2020). In the present study, artificially contaminated skinless chicken samples using a high initial concentration of C. jejuni allowed to determine the reduction kinetics of the wild-type strain, over the course of refrigeration and simulated cooking, which would not be feasible using naturally contaminated samples. Such a strategy provided data for stablishing regular time intervals to be evaluated in future studies of the mean log reduction of $C$. jejuni in naturally contaminated skinless chicken, in which a lower Campylobacter number would be expected.

Taken together, significant effects of exposure times and experimental blocks were found on the survival of C. jejuni in skinless chicken meat at $6^{\circ} \mathrm{C}$ and $70^{\circ} \mathrm{C}$, but without achieving the complete inactivation of the initial inoculum. The survival kinetics of the wild-type strain on chicken surface showed $0.26 \mathrm{log}$ 
linear reduction in $C$. jejuni $\left(\mathrm{CFU} \mathrm{g}^{-1}\right)$ for each day of evaluation at $6^{\circ} \mathrm{C}$, whereas $1.35 \log$ reduction was found in $C$. jejuni $\left(\mathrm{CFU} \mathrm{g}^{-1}\right)$ for each increase of $1 \mathrm{log}$ in the exposure period in minutes to $70^{\circ} \mathrm{C}$. Further studies using naturally contaminated chicken samples from the Brazilian food chain would validate the effect of chilling and cooking on the reduction of $C$. jejuni. The results underline the importance of good hygiene practices for handling and cooking chicken in the domestic environment to prevent foodborne campylobacteriosis.

\section{Acknowledgments}

To Conselho Nacional de Desenvolvimento Científico e Tecnológico (CNPq, grant number 477431/2013-5), and to Empresa Brasileira de Pesquisa Agropecuária (Embrapa, grant number 030860400), for financial support.

\section{References}

AL-SAKKAF, A. Campylobacter heat resistance-past, current status and future prospect for New Zealand and beyond. World's Poultry Science Journal, v.71, p.111-124, 2015. DOI: https://doi.org/10.1017/S0043933915000100.

BOYSEN, L.; WECHTER, N.S.; ROSENQUIST, H. Effects of decontamination at varying contamination levels of Campylobacter jejuni on broiler meat. Poultry Science, v.92, p.1425-1429, 2013. DOI: https://doi.org/10.3382/ps.2012-02889.

CASAGRANDE PROIETTI, P.; PERGOLA, S.; BELLUCCI, S.; MENCHETTI, L.; MIRAGLIA, D.; FRANCIOSINI, M.P. Occurrence and antimicrobial susceptibility of Campylobacter spp. on fresh and refrigerated chicken meat products in Central Italy. Poultry Science, v.97, p.2895-2901, 2018. DOI: https://doi.org/10.3382/ps/pey147.

de JONGE, R. Predictable and unpredictable survival of foodborne pathogens during non-isothermal heating. International Journal of Food Microbiology, v.291, p.151-160, 2019. DOI: https://doi.org/10.1016/j.ijfoodmicro.2018.11.018.

GOMES, C.N.; PASSAGLIA, J.; VILELA, F.P.; SILVA, F.M.H.S.P. da; DUQUE, S.S.; FALCÃO, J.P. High survival rates of Campylobacter coli under different stress conditions suggest that more rigorous food control measures might be needed in Brazil. Food Microbiology, v.73, p.327-333, 2018. DOI: https://doi.org/10.1016/j.fm.2018.02.014.

HANSSON, I.; SANDBERG, M.; HABIB, I.; LOWMAN, R.; ENGVALL, E.O. Knowledge gaps in control of Campylobacter for prevention of campylobacteriosis. Transboundary and
Emerging Diseases, v.65, p.30-48, 2018. Special Issue, Supp. DOI: https://doi.org/10.1111/tbed.12870.

LAHOU, E.; WANG, X.; BOECK, E. de; VERGULDT, E.; GEERAERD, A.; DEVLIEGHERE, F.; UYTTENDAELE, M. Effectiveness of inactivation of foodborne pathogens during simulated home pan frying of steak, hamburger or meat strips. International Journal of Food Microbiology, v.206, p.118-129, 2015. DOI: https://doi.org/10.1016/j.ijfoodmicro.2015.04.014.

LANGSRUD, S.; SØRHEIM, O.; SKULAND, S.E.; ALMLI, V.L.; JENSEN, M.R.; GRØVLEN, M.S.; UELAND, Ø.; MØRETRØ, T. Cooking chicken at home: common or recommended approaches to judge doneness may not assure sufficient inactivation of pathogens. PLoS ONE, v.15, e0230928, 2020. DOI: https://doi.org/10.1371/journal.pone.0230928.

MELO, R.T.; GRAZZIOTIN, A.L.; VALADARES JÚNIOR, E.C.; PRADO, R.R.; MENDONÇA, E.P.; MONTEIRO, G.P.; PERES, P.A.B.M.; ROSSI, D.A. Evolution of Campylobacter jejuni of poultry origin in Brazil. Food Microbiology, v.82, p.489-496, 2019. DOI: https://doi.org/10.1016/j.fm.2019.03.009.

MEMBRÉ, J.-M.; LAROCHE, M.; MAGRAS, C. Meta-analysis of Campylobacter spp. survival data within a temperature range of 0 to $42^{\circ}$ C. Journal of Food Protection, v.76, p.1726-1732, 2013. DOI: https://doi.org/10.4315/0362-028X.JFP-13-042.

POZZA, J. dos S.; VOSS-RECH, D.; LOPES, L. dos S.; VAZ, C.S.L. Research Note: a baseline survey of thermotolerant Campylobacter in retail chicken in southern Brazil. Poultry Science, v.99, p.2690-2695, 2020. DOI: https://doi.org/10.1016/j.psj.2019.12.061.

RAMIRES, T.; OLIVEIRA, M.G. de; KLEINUBING, N.R.; FÁTIMA RAUBER WÜRFEL, S. de; MATA, M.M.; IGLESIAS, M.A.; LOPES, G.V.; DELlAGOSTIN, O.A.; SILVA, W.P. da. Genetic diversity, antimicrobial resistance, and virulence genes of thermophilic Campylobacter isolated from broiler production chain. Brazilian Journal of Microbiology, v.51, p.2021-2032, 2020. DOI: https://doi.org/10.1007/s42770-020-00314-0.

RITZ, M.; NAUTA, M.J.; TEUNIS, P.F.M.; LEUSDEN, F. van; FEDERIGHI, M.; HAVELAAR, A.H. Modelling of Campylobacter survival in frozen chicken meat. Journal of Applied Microbiology, v.103, p.594-600, 2007. DOI: https://doi.org/10.1111/j.1365-2672.2007.03284.x.

SAMPERS, I.; HABIB, I.; DE ZUTTER, L.; DUMOULIN, A.; UYTTENDAELE, M. Survival of Campylobacter spp. in poultry meat preparations subjected to freezing, refrigeration, minor salt concentration, and heat treatment. International Journal of Food Microbiology, v.137, p.147-153, 2010. DOI: https://doi.org/10.1016/j.ijfoodmicro.2009.11.013.

THE EUROPEAN Union One Health 2018 Zoonoses Report. EFSA Journal, v.17, e05926, 2019. DOI: https://doi.org/10.2903/j.efsa.2019.5926. 